\title{
Peningkatan Motivasi Dan Hasil Belajar Siswa Di Masa Pandemi Covid 19 Dengan Media Pembelajaran Kinemaster Di SMP Negeri 8 Pagar Alam
}

\author{
Ise Fitrilia dan Tri Rohani \\ STKIP Muhammadiyah Pagar Alam, Indonesia \\ Email Korespondensi: isefitrilia@gmail.com
}

\begin{abstract}
Penelitian ini berdasarkan permasalahan: Apakah penerapan media pembelajaran dengan menggunakan aplikasi kinemaster dapat meningkatkan hasil belajar dan motivasi peserta didik kelas IX.E SMP Negeri 8 Pagar Alam? Penelitian ini bertujuan untuk meningkatkan motivasi dan hasil belajar siswa di era pandemi covid 19 melalui media pembelajaran kinemaster. Hal ini dilakukan berdasarkan observasi dan pengalaman penulis dalam proses pembelajaran online. Penelitian ini menggunakan penelitian tindakan kelas (action research) sebanyak tiga siklus. Setiap siklus terdiri dari empat tahap yaitu: Rancangan Tindakan (planning), Pelaksanaan Tindakan (Acting), Pengamatan (Observing), Refleksi (reflecting)). Sasaran penelitian ini adalah siswa Kelas IX.E. Data yang diperoleh berupa hasil tes formatif dan pengumpulan angket motivasi belajar. Dari hasil analisis didapatkan bahwa hasil belajar siswa mengalami peningkatan dari siklus I sampai siklus III yaitu, siklus I (71\% dengan rata-rata nilai $70,62)$, siklus II ( $81 \%$ dengan rata-rata 75,93$)$, siklus III (90\% dengan rata-rata 85$)$. Motivasi belajar siswa mengalami peningkatan, pada siklus I (rata-rata 48,09 dengan kategori sedang), siklus II (rata-rata 54,03 dengan kategori tinggi), dan siklus III (rata-rata 71,93 dengan kategori tinggi). Simpulan dari penelitian ini adalah penerapan media pembelajaran dengan menggunakan aplikasi kinemaster dapat meningkatkan hasil belajar dan motivasi peserta siswa kelas IX.E SMP Negeri 8 Pagar Alam.
\end{abstract}

Kata kunci: Kinemaster, hasil belajar, covid-19

\section{PENDAHULUAN}

Berdasarkan Surat Edaran Nomor 4 Tahun 2020 tentang Pelaksanaan Kebijakan Pendidikan dalam masa darurat penyebaran virus, Mendikbud menghimbau agar semua lembaga pendidikan tidak melakukan proses belajar mengajar secara langsung atau tatap muka, melainkan harus dilakukan secara tidak langsung atau jarak jauh. Dengan adanya himbauan tersebut membuat semua lembaga pendidikan mengganti metode pembelajaran yang digunakan yaitu menjadi online atau dalam jaringan (daring).

Keadaan ini tentu saja memberikan dampak pada kualitas pembelajaran, siswa dan guru yang sebelumnya berinteraksi secara langsung dalam ruang kelas sekarang harus berinteraksi dalam ruang virtual yang terbatas. guru dituntut memberikan pengajaran yang baik, menciptakan suasana yang kondusif untuk belajar dan secara kreatif dan inovatif menggunakan media belajar yang menarik agar siswa dapat memahami materi pembelajaran dan tujuan pembelajaran dapat tercapai.

Selain itu, motivasi belajar siswa juga berpengaruh dalam keberhasilan pembelajaran. Hal ini sesuai dengan yang diungkapkan oleh Emda bahwa proses pembelajaran akan mencapai 
keberhasilan apabila siswa memiliki motivasi belajar yang baik. Oleh karena itu motivasi belajar sangat penting untuk dimiliki oleh setiap siswa, baik motivasi intrinsik maupun ekstrinsik. Iklim belajar yang diciptakan pembelajaran daring turut mempengaruhi motivasi belajar siswa, jika dalam pembelajaran luring guru mampu menciptakan suasana kelas kondusif untuk menjaga motivasi belajar siswa agar pembelajaran dapat tercapai karena iklim kelas memiliki pengaruh yang signifikan dengan motivasi belajar. Namun kondisi pembelajaran daring menyebabkan guru kesulitan untuk mengontrol dan menjaga iklim belajar karena terbatas dalam ruang virtual. Kondisi ini menyebabkan motivasi belajar siswa dapat menurun bahkan mempengaruhi hasil belajar siswa.

Berdasarkan pengalaman pribadi selaku guru, ada beberapa permasalahan yang peneliti hadapi dalam proses belajar mengajar di kelas, antara lain sebagai berikut : (1) siswa kurang aktif dan kurang bersemangat dalam mengikuti proses belajar mengajar, (2) siswa kurang memiliki keberanian untuk bertanya dan menjawab pertanyaaan dalam menyampaikan pendapat ataupun gagasan pada saat kegiatan pembelajaran Online berlangsung, (3) kurangnya motivasi siswa untuk mengerjakan tugas yang diberikan, (4) dalam kegiatan pembelajaran, guru hanya memberikan video pembelajaran seperti, guru menjelaskan didepan kelas, divideokan oleh rekan kerja dan di sharekan kepada peserta didik, siswa hanya sebagai objek belajar dan siswa hanya menerima transfer pengetahuan dari guru saja.hanya sedikit yang berpartisipasi dan aktif dalam pembelajaran, (5) Terkadang guru juga memberikan penjelasan berupa teks, ada beberapa peserta didik yang malas membaca sehingga tidak menghiraukan materi yang diberikan (6)begitu juga dengan hasil belajar siswa yang didapat dari nilai ulangan harian yang masih dibawah KKM.

Melihat kondisi demikian perlu dicarikan solusi alternatif dalam pembelajaran dan daya tarik dalam pembelajaran, supaya segala permasalahan serta kendala yang terdapat dalam siswa maupun guru dapat teratasi maka diperlukan media pembelajaran yang memudahkan siswa untuk aktif dan ikut berpartisipasi dalam proses pembelajaran yaitu media kinemaster.

Peneliti memilih media pembelajaran berbasis kinemaster karena sudah ada hasil penelitian yang menunjukkan berhasilnya penerapan media pembelajaran ini. Adapun penelitian tersebut yaitu : Pembelajaran Teks Report dengan Proyek "Cerdig" Berbasis Kinemaster yang ditulis oleh Laily Amin Fajariyah pada tahun 2018 menyatakan hampir semua siswa menyatakan setuju apabila pembelajaran Bahasa Inggris dengan proyek cerdig berbasis Kinemaster itu menyenangkan. Hanya ada 1 (satu) siswa yang tidak yakin atas jawabannya. Karena merasa senang dan termotivasi, partisipasi siswa juga meningkat. Dengan meningkatnya partisipasi siswa dalam pembelajaran dan perasaan senang di kelas, media pembelajaran Kinemaster ini diyakini dapat meningkatkan pemahaman serta hasil belajar siswa.

Selain meningkatkan pemahaman siswa, proyek ini juga diyakini mampu meningkatkan keterampilan berbicara mereka, terutama dalam keterampilan berbicara secara monologue, khususnya aspek pelafalan dan kelancaran. Robyler \& Doering (2013: 25) menyatakan bahwa teknologi mampu melibatkan siswa dalam karya produksi. Dalam hal ini, produksi bahasa Inggris dalam bentuk cerita digital. Kinemaster juga dapat meningkatkan keterampilan peserta didik dalam teknologi informasi dan komunikasi (TIK) antara lain dalam mengunduh gambar, melakukan digital storytelling dengan Kinemaster, dan mengakses youtube.

Penelitian ini, menuntut siswa berperan aktif mengikuti pembelajaran yang dilakukan oleh guru. Dengan arahan yang diberikan oleh guru, yakni menuliskan teks prosedur ke dalam media kinemaster berdasarkan struktur teks prosedur yang berlaku didalam buku Bahasa Inggris kelas IX SMP, membuat teks prosedur menjadi lebih menarik lagi dengan adanya media tersebut. 
Berdasarkan latar belakang tersebut, penulis tertarik melakukan penelitian dengan judul "Peningkatan motivasi dan hasil belajar siswa di masa pandemi covid 19 dengan media pembelajaran kinemaster di SMP Negeri 8 Pagar Alam."

\section{Konsep Motivasi}

Kata "motif" dapat diartikan sebagai upaya yang mendorong seseorang untuk melakukan sesuatu. Berawal dari kata motif maka motivasi dapat diartikan sebagai daya penggerak (Sardiman, 2007: 73). Dalam kamus besar bahasa indonesia, indikator adalah alat pemantau (sesuatu) yang dapat memberikan petunjuk atau keterangan (Depdikbud, 1991.

Indikator motivasi menurut Slameto (2010) adalah: rasa suka atau rasa ketertarikan pada suatu hal atau aktivitas, tanpa ada yang menyuruh, keseriusan dalam melakukan aktivitas di kelas, adanya kesiapan siswa untuk mengikuti pelajaran di kelas, penerimaan akan suatu hubungan antara diri sendiri dengan sesuatu di luar diri, dan partisipasi siswa dalam suatu aktivitas. Indikator yang digunakan dalam penelitian ini adalah: penguasaan siswa terhadap materi yang diberikan, rasa suka atau ketertarikan pada suatu hal atau aktivitas, tanpa ada yang menyuruh, keseriusan siswa dalam melakukan aktivitas pelajaran di, partisipasi siswa dalam suatu aktivitas yang akan dianalisa dengan observasi dan angket motivasi.

\section{Hasil Belajar}

Hasil belajar merupakan pola-pola perbuatan, nilai-nilai, pengertian-pengertian, sikap-sikap, apresiasi dan keterampilan (Suprijono, 2009:5). Menurut Dr. Nana Sudjana hasil belajar siswa adalah perubahan tingkah laku. Jenis-jenis hasil belajar menurut Bloom dalam Mustaqim (2008) membedakan menjadi 3 ranah (domain), yaitu ranah kognitif, afektif dan psikomotor. Istilah hasil belajar mempunyai hubungan yang erat kaitannya dengan prestasi belajar. Sesungguhnya sangat sulit untuk membedakan pengertian prestasi belajar dengan hasil belajar. Ada yang berpendapat bahwa pengertian hasil belajar dianggap sama dengan pengertian prestasi belajar. Akan tetapi lebih dahulu sebaiknya kita simak pendapat yang mengatakan bahwa hasil belajar berbeda secara prinsipil dengan prestasi belajar. Adapun hasil belajar dalam penelitian ini akan menjadi tolak ukur peneliti untuk menentukan keberhasilan media pembelajaran yang digunakan.

\section{Konsep Kinemaster}

Kinimaster merupakan aplikasi untuk mengedit video dengan tampilan komputer dengan tampilan ponsel. Aplikasi ini mendukung banyak lapisan video, audio, gambar, teks, dan efek. Video kinimaster dapat juga langsung dibagikan pada platform media sosial. Kinemaster adalah salah satu program penyuntingan video secara profesional yang bisa digunakan di smartphone (www.kinemaster.com, 2017). Fajariyah (2017: 154-7) menyampaikan langkahlangkah menggunakan Kinemaster untuk pembuatan cerita digital sebagai berikut: membuat proyek baru, memasukkan visuals/video dari media browser,memasukkan audio (recording atau file), memberikan efek dan menyunting timeline, menyimpan save video. Pada langkah terakhir menyimpan video (save video). 


\section{METODE PENELITIAN}

Penelitian yang peneliti gunakan ialah Penelitian Tindakan Kelas (PTK). Penelitian Tindakan Kelas (PTK) merupakan penelitian yang dilakukan oleh guru di dalam kelasnya sendiri melalui refleksi diri dengan tujuan untuk memperbaiki kualitas pembelajaran di kelas, sehingga hasil belajar siswa dapat ditingkatkan (Daryanto, 2011:3). penelitian akan dilakukan dengan beberapa siklus, sesuai dengan kriteria yang telah ditentukan yaitu; $85 \%$ siswa mendapatkan nilai KKM dan motivasi siswa dalam categori tinggi. Setiap siklus dilakukan dalam empat tahap yaitu: perencanaan, pelaksanaan, observasi, dan refleksi.

\section{Teknik Analisis Data}

Teknik analisis data dalam penelitian ini akan dilaksanakan dengan dua cara yaitu;kualitatif dan kuantitatif. Kualitatif data didapat dari hasil angket motivasi siswa, sedangkan data kuantitatif didapat dari hasil tes kognitif (hasil belajar).

\section{HASIL PENELITIAN DAN PEMBAHASAN}

Data penelitian yang diperoleh berupa data tes formatif dari siklus 1 sampai siklus 3 untuk mengetahui peningkatan prestasi belajar siswa dan data angket dari siklus 1 sampai dengan siklus 3 diambil untuk mengetahui motivasi siswa dalam proses pembelajaran dikelas setelah diterapkan media pembelajaran berbasis kinemaster adalah sebagai berikut.

Tabel 2. Rekapitulasi Hasil belajar Tes Formatif Siklus I, II, III

\begin{tabular}{|l|c|c|c|}
\hline \multicolumn{1}{|c|}{ Uraian } & Siklus 1 & $\begin{array}{c}\text { Hasil belajar } \\
\text { Siklus 2 }\end{array}$ \\
\hline Nilai rata-rata & 70,62 & 75,93 & 83 \\
\hline Persentase ketuntasan & $71 \%$ & $81 \%$ & $90 \%$ \\
\hline Jumlah siswa yang tuntas & 23 & 26 & 29 \\
\hline
\end{tabular}

Berdasarkan rekapitulasi diatas hasil peneilitian ini menunjukkan bahwa penerapan pembelajaran berbasis kinemaster dapat meningkatkan hasil belajar siswa, hal ini dapat dilihat dari peningkatan hasil belajar siswa dari siklus 1 sampai siklus III. (ketuntasan belajar meningkat dari sIklus I, II, dan III) yaitu masing-masing 71\%, 81\%, dan 90\% dengan rata-rata nilai 70,62 pada siklus 1, 75,93 pada siklus II dan 85 pada siklus III. Pada siklus III ketuntasan belajar siswa secara klasikal telah tercapai). Hal ini didukung oleh penelitian sebelumnya yang dilaksanakan oleh Eka Indriani. 2019 yang menyatakan bahwa penggunaan media kinemaster dapat meningkatkan hasil belajar siswa".

Tabel 3. Rekapitulasi Hasil angket motivasi Pada Siklus I, II, III

\begin{tabular}{|l|c|c|c|}
\hline \multirow{2}{*}{ Uraian } & \multicolumn{3}{c|}{ Angket motivasi } \\
\cline { 2 - 4 } & Siklus 1 & Siklus 2 & Siklus 3 \\
\hline Nilai rata-rata & 48,09 & 54,03 & 71,93 \\
\hline Kategori & Sedang & Tinggi & Tinggi \\
\hline
\end{tabular}

Berdasarkan hasil rekapitulasi motivasi diatas menunjukan bahwa motivasi pembelajaran berbasis kinemaster dapat meningkatkan motivasi belajar, hal ini dapat dilihat dari peningkatan hasil angket motivasi siswa dari siklus 1 sampai siklus III. (rata-rata motivasi siswa meningkat dari sIklus I, II, dan III) siklus 1 yaitu 48,09 dengan kategori sedang, siklus II yaitu 
54,03 dengan kategori tinggi dan siklus III yaitu 71,93 dengan kategori tinggi. Pada siklus II dan III ketuntasan belajar siswa secara klasikal telah tercapai.

\section{KESIMPULAN}

Dari hasil kegiatan pembelajaran yang telah dilakukan selama tiga siklus, dan berdasarkan seluruh pembahasan serta analisis yang telah dilakukan dapat disimpulkan bahwa penerapan media pembelajaran berbasis kinemaster dapat meningkatkan hasil belajar siswa yang ditandai dengan peningkatan ketuntasan belajar siswa dalam setiap siklus, yaitu, siklus I (71\% dengan rata-rata nilai 70,62), siklus II (81\% dengan rata-rata 75,93), siklus III (90\% dengan rata-rata 85). Selanjutnya, Penerapan media pembelajaran berbasis kinemaster juga dapat meningkatkan motivasi belajar siswa yang ditandai dengan peningkatan setiap siklus, pada siklus I (rata-rata 48,09 dengan kategori sedang), siklus II (rata-rata 54,03 dengan kategori tinggi), dan siklus III (rata-rata 71,93 dengan kategori tinggi). Kesimpulan dari penelitian ini adalah penerapan media pembelajaran dengan menggunakan aplikasi kinemaster dapat meningkatkan hasil belajar dan motivasi peserta siswa kelas IX.E SMP Negeri 8 Pagar Alam.

\section{DAFTAR PUSTAKA}

Adhety Cahyani, dkk. "Motivasi Belajar siswa SMA pada pembelajaran Daring dimasa pandemi Covid-19” Jurnal Pendidikan Islam Volume 3 No.01 2020, p.123-140

Aqib, Zainal, dkk. 2010. Penelitian Tindakan Kelas. Bandung: Yrama Widya

BSNP. 2007. Pedoman Penilaian Hasil Belajar di Sekolah Dasar. Jakarta: Depdiknas

Daryanto. 2011. Penelitian Tindakan Kelas dan Penelitian Tindakan Sekolah. Yogyakarta: Gava Media.

Eka Indriani. 2019."Efektivitas Penggunaan media kinemaster terhadap kemampuan menulis teks procedure siswa kelas VII SMP Swasta Muhammadiyah 05 Medan”.

Elliot, J. (1998). Action Research for Education Change. Philadelphia: Open University Press.

Emda, Amna. Kedudukan motivasi belajar siswa dalam pembelajaran". Lantanida Jurnal 5, no.2 (2018); 172-182

Fajariyah, L.A. 2018. Pembelajaran Teks Report Dengan Proyek "CERDIG" berbasis kinemaster. Jurnal Didaktika Pendidikan Dasar, Volume 1 Nomor 1 Tahun 2018. 182192

Gowing, Marilyn K. "Measurement of Individual Emotional Competence" dalam Daniel Goleman, Cary Cherniss (ed.). The emotionally intelligent workplace: How to select for, measure, and improve emotional intelligence in individuals, groups, and organizations. (Fransisco: Jossey-Bass, 2001)

Kardian. 2014. “ Peningkatan Motivasi Belajar Siswa Kelas X Melalui Media Audio Visual Pada Mata Pelajaran PAI di SMK Karya Ekopin.

Nana Sudjana. 2012. Penilaian Hasil Proses Belajar Mengajar. Bandung: Remaja Rosdakarya.

Sardiman. 2007. Interkasi dan Motivasi Belajar mengajar. Jakarta: PT Raja grafindo Persada. Slameto. 2010. Belajar dan Faktor-Faktor yang Mempengaruhi. Jakarta:Rineka Cipta. Sudjana, Nana. 2010. Penilaian Proses Belajar Mengajar. Bandung: PT. Remaja Rosdakarya.

Suprijono, A.2009. Cooperative Learning Teori dan Aplikasi PAIKEM. Yogyakarta: Pustaka Pelajar 